Research Article

\section{Circulating salusin-beta levels in the patients with age-related macular degeneration}

\author{
Burak Turgut $^{1 *}$, Kadir Mercan², Nesrin Demir ${ }^{3}$, Nevin Ilhan ${ }^{4}$ \\ and Onur Çatak ${ }^{5}$
}

\author{
${ }^{1}$ Department of Ophthalmology, Faculty of Medicine, Onsekiz Mart University, Çanakkale, Turkey \\ ${ }^{2}$ Universal Eye Hospital, Malatya, Turkey \\ ${ }^{3}$ Department of Immunology, Faculty of Medicine, Onsekiz Mart University, Çanakkale, Turkey \\ ${ }^{4}$ Department of Biochemistry, Faculty of Medicine, Fırat University, Elazığ, Turkey \\ ${ }^{5}$ Department of Ophthalmology, Faculty of Medicine, Fırat University, Elazığ, Turkey
}

\section{Abstract}

Purpose: To evaluate the levels of salusin-beta ( $\beta-S A L)$ in the serum in patients with agerelated macular degeneration (ARMD).

Methods: Our study was designed as a controlled comparative clinical study. The $\beta$-SAL levels in serums of age and sex-matched 20 healthy volunteers as controls (Group 1), 20 patients with dry-age related macular degeneration (d-ARMD) (Group 2) and 20 patients with wet-age related macular degeneration (w-ARMD) (Group 3) were measured with the enzyme-linked immunosorbent assay (ELISA) method.

Results: In our study, it was found that age and gender didn't show a statistically significant difference among the study groups $(p>0.05)$. The mean serum $\beta$-SAL levels in Group 1, Group 2 and Group 3 were $1372,17 \pm 1126.69 \mathrm{pg} / \mathrm{mL} ; 1423,71 \pm 1196.84 \mathrm{pg} / \mathrm{mL}$ and 940,57 \pm 1092.05 $\mathrm{pg} / \mathrm{mL}$, respectively. Although the mean $\beta$-SAL levels in w-ARMD seem numerically lower than both the control and d-ARMD groups, this difference among the study groups was not statistically significant $(p>0.05)$.

Conclusion: Our study suggests that $\beta$-SAL levels in the patients with ARMD and healthy controls were not different than each other. Further studies with large numbers may reveal possible relationships between $\beta-S A L$ and ARMD.

\section{More Information}

*Address for Correspondence: Burak Turgut Professor, MD, Department of Ophthalmology, Faculty of Medicine, Onsekiz Mart University, 17270 Çanakkale, Turkey, Tel: +905337128389; Email: burakturgut@comu.edu.tr

Submitted: December 12, 2020

Approved: February 10, 2021

Published: February 11, 2021

How to cite this article: Turgut B, Mercan K, Demir N, Ilhan N, Çatak O. Circulating salusinbeta levels in the patients with age-related macular degeneration. Int J Clin Exp Ophthalmol. 2021; 5: 001-005.

DOI: 10.29328/journal.ijceo.1001034

ORCiD: orcid.org/0000-0002-5393-0557

Copyright: @ 2021 Turgut B, et al. This is an open access article distributed under the Creative Commons Attribution License, which permits unrestricted use, distribution, and reproduction in any medium, provided the original work is properly cited.

Keywords: Age-related macular degeneration Dry; Wet; Salusin beta; Serum levels

Check for updates

OPEN ACCESS

\section{Introduction}

Age-related macular degeneration (ARMD) is aleading cause of irreversible visual loss in over 65 years' older subjects. The two types of ARMD are non-neovascular (dry, non-exudative) and neovascular (wet, exudative) type. Wet ARMD (w-ARMD) is characterized by choroidal neovascular membrane (CNVM) that is due to the formation of abnormal blood vessels, which grow from the choroid into or under the retina [1-10]. Although its pathogenesis is not currently well-understood, it has been considered that ARMD is a multifactorial disease [14]. Additionally, it has been considered that chronic low level inflammation could lead to oxidative stress and degeneration associated with ARMD [1-10].

Salusins, salusin-alpha, and salusin-beta ( $\beta$-SAL) are soluble peptide hormones processed from the same precursor peptide. Salusins are secreted in blood vessels, monocytes, and macrophages and exist in human body fluids. They stimulate the proliferation of vascular smooth muscle cells (VSMC) and fibroblasts. $\beta$-SAL has various functions including cytokine function and modulation of vascular inflammation and oxidative damage. In recent studies, it has been demonstrated that $\beta$-SAL could promote inflammation by increasing activation of nuclear factor kappa B (NF-kB) signaling pathway. Additionally, it has been reported that inhibition of $\beta$-SAL alleviates oxidative stress and inflammation in diabetic rats [11-25]. To the best of our knowledge, there have been no previous reports in the literature on the blood levels of salusin in patients with ARMD. However, in a recent study, it has been reported that the mean serum $\beta$-SAL level in the patients with 
Behcet's Disease was significantly higher compared to healthy controls [26]. An experimental study by Xu, et al. showed that $\beta$-SAL contributes to vascular inflammation associated with pulmonary arterial hypertension [13]. In this study, based on recent evidence, we hypothesized that $\beta$-SAL might play a role in ARMD pathogenesis, and aimed to evaluate the levels of $\beta$-SAL in the serum in patients with ARMD.

\section{Material and methods}

This study was performed in accordance with the Helsinki Declaration and approved by the institutional ethics committee. Informed consents were obtained from the participants. The study was conducted as a clinical comparative study and it included three groups:

Group 1 consisting sex- and age-matched 20 healthy control subjects presenting for routine eye examination with or without other ocular disorders, but without evidence of drusen, retina pigment epithelial (RPE) changes or choroidal neovascular membrane (CNVM).

Group 2 consisting 20 patients with d-ARMD characterized by RPE changes or/and macular drusen or the presence of geographic atrophy without CNVM or scarring documented by color fundus imaging, FFA and optical coherence tomography (OCT).

Group 3 consisting 20 patients with wet-ARMD with the CNVM or disciform scar documented by FFA and OCT.

A systemic examination and taking of a detailed medical story were obtained to identify the patients with risk factors for hypertension (HT), diabetes mellitus (DM), morbid obesity, hyperlipidemia, cardiovascular, and cerebrovascular diseases. The patients with hematological, neoplastic, connective, immune, cardiac, cerebrovascular, renal or hepatic diseases, DM, HT, vasculitis, morbid obesity and the patients with any ocular or systemic infection and inflammation, retinal vasoocclusive disease and the patients underwent retinal laser photocoagulation and intra-vitreal injection were excluded from the study.

A full ophthalmic examination including visual acuity, biomicroscopy, tonometry, dilated ophthalmoscopy, color fundus imaging, fundus fluorescein angiography (FFA) and OCT was performed for all participants. Clinical diagnosis and classification of ARMD to d-ARMD or w-ARMD types were performed by a single retina specialist.

Blood samples were taken from participants to measure $\beta$-SAL levels at 08.00 hours after overnight fasting and were delivered to the laboratory within $20 \mathrm{~min}$, centrifuged (2000 xg for $10 \mathrm{~min}$ at $4^{\circ} \mathrm{C}$ ) and the sera aliquot is stored at $-80^{\circ} \mathrm{C}$ until assayed. Commercial kit (Sunredbio, Baoshan, Shangai) was used for $\beta$-SAL measurement. The samples were assayed by enzyme-linked immunosorbent test (ELISA) according to the manufacturer's instructions. The minimum detectable level (sensitivity) was less than $8.756 \mathrm{pg} / \mathrm{mL}$ and the assay range was $10-3000 \mathrm{pg} / \mathrm{mL}$. Intra- and interassay CVs were less than $10 \%$ and $12 \%$, respectively. All samples were measured spectrophotometrically via EL x 800 ${ }^{\mathrm{TM}}$ Absorbance Microplate Reader (BioTek Instruments, Inc., Winooski, VT, USA) at $450 \mathrm{~nm}$. The biochemist was blind to the identity of samples during processing. The results were presented as "pg/mL".

\section{Statistical analysis}

Statistical analysis of data was performed by Statistical Package for Social Sciences, version 11.0 (SPSS Inc., Chicago, IL). Results were given as means \pm SD. Individual group parameters were assessed with the one-sample KolmogorovSmirnov $Z$ test and were found to be abnormally distributed $(p<0.05)$. The non-parametric Kruskal-Wallis and MannWhitney $U$ test were used for statistical comparisons between groups. Spearman's Rank order correlation coefficients were used to assess significant associations between $\beta$-SAL levels and demographic findings. For all comparisons, statistical significance was defined by $p<0.05$.

\section{Results}

It was found that there was no statistically significant difference concerning age and gender among the groups $(p>0.05)$. The mean serum $\beta$-SAL levels in Group 1, Group 2 and Group 3 were 1372,17 $\pm 1126.69 \mathrm{pg} / \mathrm{mL} ; 1423,71 \pm$ $1196.84 \mathrm{pg} / \mathrm{mL}$ and 940,57 $\pm 1092.05 \mathrm{pg} / \mathrm{mL}$, respectively. Although the mean $\beta$-SAL levels in $\mathrm{w}$-ARMD seem numerically lower than both the control and d-ARMD groups, this difference among the study groups was not statistically significant $(p>0.05)$ (Table 1).

\section{Discussion}

Recent clinical studies have revealed that a number of inflammatory cytokines such as IL (interleukin)-6, IL-17A, IL-18, IL-22 and TNF- $\alpha$ have been found to be elevated either systemically in the serum or locally in the ocular tissue or fluids of patients with especially w-ARMD. Additionally, it has been considered that chronic or prolonged low level inflammation can lead to oxidative stress and degeneration associated with ARMD [27-42].

Salusin- $\alpha$ and $\beta$-SAL are newly discovered bioactive peptides derived from prosalusin. They are expressed and synthesized by various cells in many tissues such as heart,

Table 1: Comparative mean $\beta$-Salusin levels in study groups.

\begin{tabular}{|c|c|c|c|}
\hline Group & Number & $\begin{array}{c}\text { Mean } \boldsymbol{\beta} \text {-Salusin levels } \pm \text { SD } \\
(\mathbf{p g} / \mathbf{m L})\end{array}$ & $\boldsymbol{p}$ value \\
\hline Control & 20 & $1372,17 \pm 1126.69$ & Controls vs. d-AMD: $p>0.05$ \\
\hline d-AMD & 20 & $1423,71 \pm 1196.84$ & d-AMD vs. w-AMD: $p>0.05$ \\
\hline w-AMD & 20 & $940,57 \pm 1092.05$ & w-AMD vs. controls: $p>0.05$ \\
\hline
\end{tabular}

Abbreviations: d-AMD: dry-Age-related Macular Degeneration; w-AMD, wet-Agerelated Macular Degeneration; SD: Standard deviation 
liver, brain, human vascular smooth muscle cells (VSMCs), and endothelial cells. It has been considered that $\beta$-SAL stimulates proliferation of VSMCs and fibroblasts through the activation of immediate response genes such as $c$-myc and fos in rats and humans [11-25].

Recent reports have demonstrated that circulating $\beta$-SAL levels in patients with coronary artery disease, DM, and cerebrovascular disease are also significantly higher levels than healthy controls [21]. Additionally, it has been reported that circulating levels of $\beta$-SAL are lower in patients with essential HT [11-25].

It has been reported that $\beta$-SAL accelerates inflammatory responses in human endothelial cells and monocyte-endothelial adhesion and that it stimulates human macrophage foam cell formation. Secretion of $\beta$-SAL is stimulated by inflammatory cytokines such as tumor necrosis factor- $\alpha$ and lipopolysaccharide [11-25]. In recent studies, it was demonstrated that $\beta$-SAL also has a stimulatory effect on pro-inflammatory and oxidative stress molecules. In those publications, it has been reported that $\beta$-SAL induces the expression of interleukin$1 \beta$ (IL-1 $\beta$ ), monocyte chemoattractant protein-1 (MCP-1), acetyl-coenzyme A acetyltransferase 1 (ACAT-1), vascular cell adhesion molecule-1 (VCAM-1), and nicotinamide adenine dinucleotide phosphate (NADPH) oxidase 2 (Nox2), a potent source of reactive oxygen species in human umbilical vein ECs (HUVECs), the adhesion of THP-1 monocytes onto HUVECs via nuclear factor- $\kappa \mathrm{B}(\mathrm{NF}-\kappa \mathrm{B})$-mediated VCAM-1 induction [17-21]. It has been reported that $\beta$-SAL increased the ROS production attenuated by NAC, apocynin or NOX2 siRNA [20].

To the best of our knowledge, this is the first report investigating the relation of serum $\beta$-SAL level in ARMD. In our study, we found that the mean $\beta$-SAL levels in w-ARMD were numerically lower than both the control and d-ARMD groups, and however, this difference among the study groups was not statistically significant. We consider that the fact that small sample size in our study may result in this statistical insignificance. We also think that theoretically, $\beta$-SAL may contribute to the pathogenesis of ARMD because it may play a significant role through its stimulatory effects on proinflammatory and oxidative stress molecules. Thus, in the studies having large patient number, the significant results on the relationship between salusins and ARMD or other retinal diseases might revealed in the future.

In the beginning of this study, we hypothesized that the levels of $\beta$-SAL in the serum in patients with ARMD may be higher than those of healthy controls because $\beta$-SAL has a pro-inflammatory and possibly angiogenic effects. The insignificant results concerning the serum levels of $\beta$-SAL in our study may be due to a choroidal (local) vascular disease but a systemic vascular disease such as diabetes or hypertension. Additionally, the levels of $\beta$-SAL in vitreous may be different in ARMD patients than those in healthy controls and also may be lower or higher in these samples compared to serum.
The main lack of our study is lower sample number. But yet, in the light of literature, we speculate that $\beta$-SAL may contribute to the pathogenesis of ARMD. Thus, as a next step, the measurement of both vitreous and surgical removed CNVMs of levels of $\beta$-SAL in ARMD patients with and without treatment may support this theory and may give marked evidence regarding the exact role of $\beta$-SAL in ARMD pathogenesis. Further research is needed to have more information on the effects of $\beta$-SAL, and to investigate the levels of free and bound $\beta$-SAL and to determine the exact role of $\beta$-SAL in the pathogenesis of ARMD.

\section{Ackowledgment}

We thank Bayer Pharmaceuticals Turkey for the support this work via providing the biochemical Salusin-beta assay kits. Involved in the conduct of study were BT and KM. Biochemical assessments were performed by NI. Collection of data, typing, translating, preparation and editing of the manuscript were performed by BT, KM, ND and OÇ. Review and final approval of the manuscript included all authors including BT, KM, ND, NI and OÇ. The authors indicate no financial conflict of proprietary interest with this work.

\section{References}

1. Ambati J, Ambati BK, Yoo SH, lanchulev S, Adamis AP. Age-related macular degeneration: etiology, pathogenesis, and therapeutic strategies. Surv Ophthalmol. 2003; 48: 257-293.

PubMed: https://pubmed.ncbi.nlm.nih.gov/12745003/

2. Ratnapriya R, Chew EY. Age-related macular degeneration-clinical review and genetics update. Clin Genet. 2013; 84: 160-166.

PubMed: https://pubmed.ncbi.nlm.nih.gov/23713713/

3. Scholl HP, Fleckenstein M, Charbel Issa P, Keilhauer C, Holz FG, et al An update on the genetics of age-related macular degeneration. Mol Vis. 2007; 13: 196-205.

PubMed: https://pubmed.ncbi.nlm.nih.gov/17327825/

4. Moschos MM, Nitoda E, Chatziralli IP, Demopoulos CA. Age-Related Macular Degeneration: Pathogenesis, Genetic Background, and the Role of Nutritional Supplements. J Chem. 2014; 2014: Article ID 317536. 9.

5. Patel M, Chan CC. Immunopathological aspects of age-related macular degeneration. Semin Immunopathol. 2008; 30: 97-110. PubMed: https://pubmed.ncbi.nlm.nih.gov/18299834/

6. Ambati J, Atkinson JP, Gelfand BD. Immunology of age-related macular degeneration. Nat Rev Immunol. 2013; 13: 438-451. PubMed: https://pubmed.ncbi.nlm.nih.gov/23702979/

7. Copland DA, Theodoropoulou S, Liu J, Dick AD. A perspective of AMD through the eyes of immunology. Invest Ophthalmol Vis Sci. 2018; 59: AMD83-AMD92.

PubMed: https://pubmed.ncbi.nlm.nih.gov/30025105/

8. Wu J, Sun X. Complement system and age-related macular degeneration: drugs and challenges. Drug Des Devel Ther. 2019; 13: 2413-2425.

PubMed: https://pubmed.ncbi.nlm.nih.gov/31409975/

9. Kauppinen A, Paterno JJ, Blasiak J, Salminen A, Kaarniranta K Inflammation and its role in age-related macular degeneration. Cell Mol Life Sci. 2016; 73: 1765-1786.

PubMed: https://pubmed.ncbi.nlm.nih.gov/26852158/ 
10. Knickelbein JE, Chan CC, Sen HN, Ferris FL, Nussenblatt RB. Inflammatory Mechanisms of Age-related Macular Degeneration. Int Ophthalmol Clin. 2015; 55: 63-78.

PubMed: https://pubmed.ncbi.nlm.nih.gov/26035762/

11. Sato K, Watanabe R, Itoh F, Shichiri M, Watanabe T. Salusins: potential use as a biomarker for atherosclerotic cardiovascular diseases. Int $J$ Hypertens. 2013; 2013: 965140.

12. Suzuki-Kemuriyama $N$, Nakano-Tateno $T$, Tani $Y$, Hirata $Y$, Shichiri $M$ Salusin- $\beta$ as a powerful endogenous antidipsogenic neuropeptide. Sc Rep. 2016; 6: 20988.

13. Xu T, Zhang Z, Liu T, Zhang W, Liu J, Wang W, Wang J. Salusin- $\beta$ contributes to vascular inflammation associated with pulmonary arterial hypertension in rats. J Thorac Cardiovasc Surg. 2016; 152: 1177-1187. PubMed: https://pubmed.ncbi.nlm.nih.gov/27353339/

14. Zhao MX, Zhou B, Ling L, Xiong XQ, Zhang $F$, et al. Salusin- $\beta$ contributes to oxidative stress and inflammation in diabetic cardiomyopathy. Cell Death Dis. 2017; 8: e2690.

PubMed: https://pubmed.ncbi.nlm.nih.gov/28333148/

15. Cakir M, Duzova H, Taslidere A, Orhan G, Ozyalin F. Protective effects of salusin- $\alpha$ and salusin- $\beta$ on renal ischemia/reperfusion damage and their levels in ischemic acute renal failure. Biotech Histochem. 2017; 92: 122-133.

PubMed: https://pubmed.ncbi.nlm.nih.gov/28296550/

16. Koya T, Miyazaki T, Watanabe T, Shichiri M, Atsumi T, et al. Salusin- $\beta$ accelerates inflammatory responses in vascular endothelial cells via NF-KB signaling in LDL receptor-deficient mice in vivo and HUVECs in vitro. Am J Physiol Heart Circ Physiol. 2012; 303: H96-105. PubMed: https://pubmed.ncbi.nlm.nih.gov/22561298/

17. Sun HJ, Zhao MX, Liu TY, Ren XS, Chen $Q$, et al. Salusin- $\beta$ induces foam cell formation and monocyte adhesion in human vascular smooth muscle cells via miR155/NOX2/NFkB pathway. Sci Rep. 2016; 6: 23596. PubMed: https://pubmed.ncbi.nlm.nih.gov/27004848/

18. Shichiri M, Ishimaru S, Ota T, Nishikawa $T$, Isogai $T$, et al. Salusins: newly identified bioactive peptides with hemodynamic and mitogenic activities. Nat Med. 2003; 9: 1166-1172.

PubMed: https://pubmed.ncbi.nlm.nih.gov/12910263/

19. Liu J, Ren YG, Zhang LH, Tong YW, Kang L. Serum salusin- $\beta$ levels are associated with the presence and severity of coronary artery disease. J Investig Med. 2015; 63: 632-635.

PubMed: https://pubmed.ncbi.nlm.nih.gov/25730454/

20. Sun HJ, Liu TY, Zhang F, Xiong XQ, Wang JJ, et al. Salusin-b contributes to vascular remodeling associated with hypertension via promoting vascular smooth muscle cell proliferation and vascular fibrosis. Biochim Biophys Acta. 2015; 1852: 1709-1718.

PubMed: https://pubmed.ncbi.nlm.nih.gov/26001930/

21. Fujimoto $K$, Hayashi $A$, Kamata $Y$, Ogawa $A$, Watanabe $T$, et al. Circulating levels of human salusin- $\beta$, a potent hemodynamic and atherogenesis regulator. PLoS One. 2013; 8: e76714.

PubMed: https://pubmed.ncbi.nlm.nih.gov/24098553/

22. Suzuki N, Shichiri M, Akashi T, Sato K, Sakurada M, et al. Systemic distribution of salusin expression in the rat. Hypertension Res. 2007; 30: 1255-1262.

PubMed: https://pubmed.ncbi.nlm.nih.gov/18344632/

23. Izumiyama H, Tanaka H, Egi K, Sunamori M, Hirata $Y$, et al. Synthetic salusins as a cardiac depressors in rat. Hypertension. 2005; 45: 419-425. PubMed: https://pubmed.ncbi.nlm.nih.gov/15699450/

24. Chen WW, Sun HJ, Zhang F, Zhou $Y$, Xiong $X Q$, et al. Salusin- $\beta$ in paraventricular nucleus increases blood pressure and sympathetic outflow via vasopressin in hypertensive rats. Cardiovasc Res. 2013;
98: $344-351$

PubMed: https://pubmed.ncbi.nlm.nih.gov/23400761/

25. Xiao-Hong Y, Li L, Yan-Xia P, Hong L, Wei-Fang R, et al. Salusins protect neonatal rat cardiomyocytes from serum deprivation-induced cell death through upregulation of GRP78. J Cardiovasc Pharmacol. 2006; 48: 41-46.

PubMed: https://pubmed.ncbi.nlm.nih.gov/16954820/

26. Erden I, Demir B, Uçak H, Cicek D, Dertlioğlu SB, et al. Serum salusin-a and salusin- $\beta$ levels in patients with Behcet's disease. Eur J Dermatol. 2014; 24: 577-582.

PubMed: https://pubmed.ncbi.nlm.nih.gov/25115151/

27. Doyle SL, Campbell M, Ozaki E, Salomon RG, Mori A, et al. NLRP3 has a protective role in age-related macular degeneration through the induction of IL-18 by drusen components. Nat Med. 2012; 18: 791-798. PubMed: https://pubmed.ncbi.nlm.nih.gov/22484808/

28. Knickelbein JE, Chan CC, Sen HN, Ferris FL, Nussenblatt RB Inflammatory Mechanisms of Age-related Macular Degeneration. Int Ophthalmol Clin. 2015; 55: 63-78.

PubMed: https://pubmed.ncbi.nlm.nih.gov/26035762/

29. Whitcup SM, Sodhi A, Atkinson JP, Holers VM, Sinha D, Rohrer B, Dick $A D$. The role of the immune response in age-related macular degeneration. Int J Inflam. 2013; 2013: 348092. PubMed: https://pubmed.ncbi.nlm.nih.gov/23762772/

30. Malesiński R, Mrugacz M, Bakunowicz-Łazarczyk A. [The role of chemokines in ocular diseases. Part II. Participation of chemokines in ocular diseases]. Klin Oczna. 2007; 109: 340-344.

PubMed: https://pubmed.ncbi.nlm.nih.gov/18260294/

31. Wallace GR, John Curnow S, Wloka K, Salmon M, Murray PI The role of chemokines and their receptors in ocular disease. Prog Retin Eye Res. 2004; 23: 435-448.

PubMed: https://pubmed.ncbi.nlm.nih.gov/15219876/

32. Bhattacherjee

The role of arachidonate metabolites in ocular inflammation. Prog Clin Biol Res. 1989; 312: 211-227.

PubMed: https://pubmed.ncbi.nlm.nih.gov/2508125/

33. Wakefield D, Lloyd A. The role of cytokines in the pathogenesis of inflammatory eye disease. Cytokine. 1992; 4: 1-5.

PubMed: https://pubmed.ncbi.nlm.nih.gov/1617154/

34. Cao S, Ko A, Partanen M, Pakzad-Vaezi K, Merkur AB, et al. Relationship between systemic cytokines and complement factor $\mathrm{H} \mathrm{Y402H} \mathrm{polymorphism} \mathrm{in} \mathrm{patients} \mathrm{with} \mathrm{dry} \mathrm{age-related} \mathrm{macular}$ degeneration. Am J Ophthalmol. 2013; 156: 1176-1183. PubMed: https://pubmed.ncbi.nlm.nih.gov/24083687/

35. Liu B, Wei L, Meyerle C, Tuo J, Sen HN, et al. Complement component C5a promotes expression of IL-22 and IL-17 from human T cells and its implication in age-related macular degeneration. J Transl Med. 2011; 9: 1-12.

PubMed: https://pubmed.ncbi.nlm.nih.gov/21762495/

36. Ardeljan D, Wang Y, Park S, Shen D, Chu XK, et al. Interleukin-17 retinotoxicity is prevented by gene transfer of a soluble interleukin-17 receptor acting as a cytokine blocker: implications for age-related macular degeneration. PLoS One. 2014; 9: e95900. PubMed: https://pubmed.ncbi.nlm.nih.gov/24780906/

37. Li Z, Liu B, Maminishkis A, Mahesh SP, Yeh S, et al. Gene expression profiling in autoimmune noninfectious uveitis disease. J Immunol. 2008; 181: 5147-5157.

PubMed: https://pubmed.ncbi.nlm.nih.gov/18802119/

38. Chen Y, Yang P, Li F, Kijlstra A. The effects of Th17 cytokines on the inflammatory mediator production and barrier function of ARPE- 
19 cells. PLoS One. 2011; 6: e18139.

PubMed: https://pubmed.ncbi.nlm.nih.gov/21479174/

39. Chen $\mathrm{Y}$, Zhong M, Liang L, Gu F, Peng H. Interleukin-17 induces angiogenesis in human choroidal endothelial cells in vitro. Invest Ophthalmol Vis Sci. 2014; 55: 6968-6975.

40. Chen Y, Yang P, Li F, Kijlstra A. The effects of Th17 cytokines on the inflammatory mediator production and barrier function of ARPE-
19 cells. PLoS One. 2011; 6: e18139.

PubMed: https://pubmed.ncbi.nlm.nih.gov/21479174/

41. Chen $\mathrm{Y}$, Zhong $\mathrm{M}$, Liang L, Gu F, Peng $\mathrm{H}$. Interleukin-17 induces angiogenesis in human choroidal endothelial cells in vitro. Invest Ophthalmol Vis Sci. 2014; 55: 6968-6975.

42. Bora NS, Jha P, Bora PS. The role of complement in ocular pathology. Semin Immunopathol. 2008; 30: 85-95.

PubMed: https://pubmed.ncbi.nlm.nih.gov/18299835/ 